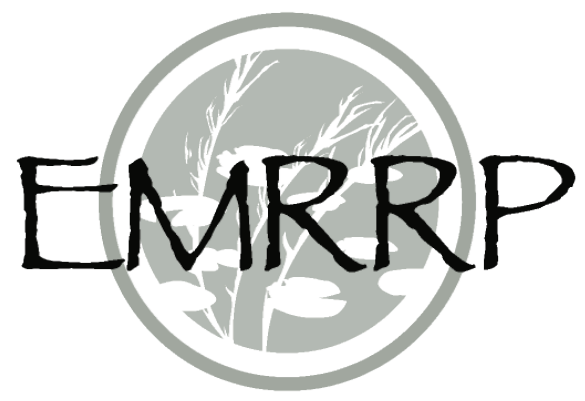

\title{
Relating Seagrass Habitat to Geomorphology and Substrate Characteristics Around Ship Island, MS
}

by Eve R. Eisemann ${ }^{1}$, Safra Altman², Damarys Acevedo-Mackey ${ }^{3}$, and Molly K. Reift

PURPOSE: Coastal vegetation, including marsh and submerged aquatic vegetation (SAV), is threatened in many places across the United States and globally. Human activity, sediment starvation, and subsidence, among other factors, put these ecosystems at risk (Kirwan and Megonigal 2013; Orth et al. 2006). One type of SAV, seagrass, is of particular ecological importance, providing food and critical habitat for numerous coastal species. However, seagrass is currently in decline globally due to the aforementioned factors (Eleuterius 1987). Identifying the necessary conditions to promote seagrass recovery and growth is highlighted as one of the "important yet essentially unanswered questions" globally in the U.S. Geological Survey's (USGS) report on seagrass coverage in the Mississippi Sound from 1940-2002 (Moncreiff 2007). In sandy barrier island systems, where seagrass habitat has been related to barrier island stability and length, there is a distinct need to quantify in detail the conditions that will promote seagrass recovery and growth (Carter et al. 2011; Eleuterius 1987; Pham et al. 2014). This report introduces a new methodology for quantifying the relationship between seagrass habitat and its physical environment, including substrate and geomorphological characteristics.

BACKGROUND: Studies relating seagrass growth to physical conditions tend to focus on finegrained estuarine environments, where wave exposure and light are identified as primary limiting factors for growth (Boer 2007; Koch 2001; Livingston et al. 1998). Important seagrass ecosystems also occur in sandy, geomorphologically dynamic barrier island systems, where controlling factors such as wave energy and rapid deposition or erosion can be much more complex (Pham et al. 2014).

Seagrass Ecosystems. Barrier island systems are ecologically unique. They form the boundary between high-energy marine environments and low-energy back-barrier marshes, bays, or sounds. Barrier islands are composed of unconsolidated sediments, and are therefore dynamic. Storms, sea-level rise, and sediment supply are the primary controlling factors of their formation,

${ }^{1}$ Research Physical Scientist, U.S. Army Engineer Research and Development Center (ERDC), Coastal and Hydraulics Laboratory (CHL), Joint Airborne Lidar Bathymetry Technical Center of Expertise (JALBTCX), Kiln, MS, (228) 239-1458, Eve.R.Eisemann@usace.army.mil

${ }^{2}$ Research Ecologist, U.S. Army Engineer Research and Development Center (ERDC), Environmental Laboratory (EL), Vicksburg, MS, (601) 634-3435, Safra.Altman@usace.army.mil

${ }^{3}$ Environmental Engineer, U.S. Army Engineer Research and Development Center (ERDC), Environmental Laboratory (EL), Vicksburg, MS, (601) 634-4845, Damarys.Acevedo-Mackey@usace.army.mil

${ }^{4}$ Research Geographer, U.S. Army Engineer Research and Development Center (ERDC), Environmental Laboratory (EL), Joint Airborne Lidar Bathymetry Technical Center of Expertise (JALBTCX) Kiln, MS, (228) 252-1134, Molly.K.Reif@usace.army.mil 
stability, or demise (Byrnes et al. 2013; McBride and Byrnes 1997; Otvos and Carter 2013; Twichell et al. 2013). Barrier islands often provide the most seaward extension of terrestrial and shallow-water ecosystems, hence, they support habitat for many coastal marine organisms (Handley et al. 2007). Seagrasses are a vital part of shallow-water ecosystems as they provide the foundation of the food chain and serve as nursery grounds to various organisms (Orth et al. 2006). Species of shellfish, finfish, crabs, and shrimp are also known to rely on seagrasses (Handley et al. 2007).

Most species of seagrass require shallow (maximum depths of 8-9 meters $(\mathrm{m})$ in the Gulf of Mexico region), low-turbidity, and low-energy environments in order to have sufficient light while avoiding currents and heavy erosion or deposition (Eleuterius 1987; Yates et al. 2011). For seagrass to colonize and grow, the substratum must be appropriate for rhizomes to establish and fasten. Areas with very mobile substrate conditions; for example, sediments within the surf zone or in an area with fast currents, are unsuitable for seagrass growth (Iverson and Bittaker 1986). Severe storms can also impact seagrass distribution, causing them to be buried or washed away (Eleuterius 1987). However, seagrass patches have been observed to withstand storm impacts with some protection from waves (Byron and Heck 2006; Carter et al. 2011).

In some cases, the presence of seagrass can facilitate sediment deposition and stabilization by slowing bottom currents and fastening the sediments in their roots. This suggests that certain low-depositional rates are tolerable for seagrass. Rapid placement of material thick enough to completely cover the seagrass, however, will prevent photosynthesis and kill the plants, although this has not been quantified in a scientific study (Yates et al. 2011).

Study Site. Ship Island, Mississippi, a member of the Mississippi-Alabama (MS-AL) Barrier Island Chain and Gulf Islands National Seashore, is the aerially and volumetrically smallest island in the chain and has been breached periodically throughout its recorded history (Morton 2008; Otvos and Carter 2008). The inlet between East and West Ship Island, opened by Hurricane Camille's impact in 1969, severely reduces the available seagrass habitat by exposing the back barrier to higher wave and current energy (USACE 2014). The only seagrass species present around Ship Island is Halodule wrightii (Ascherson), or shoal grass (Carter et al. 2011; Eleuterius 1987; Handley et al. 2007). This species has been dominant along the MS-AL barriers since 1978 (Eleuterius 1987).

H. wrightii is found growing in a variety of grain sizes, ranging from clay and silt to sand (Iverson and Bittaker 1986). In coastal Mississippi and Alabama, however, the species is typically found in sandy areas like those surrounding the barriers (Eleuterius 1987). This species has a shallow root system and often appears early in the successional development of seagrass beds (Dawes 1987). H. wrightii was found to withstand the most exposure above water level during low-tide compared with other seagrass species growing in Tampa Bay. It was also observed dominating both the deep- and shallow-water fringes of multi-species seagrass beds, though its ideal habitat is closer to sea level (Yates et al. 2011). Along the Mississippi barrier islands, this species of seagrass contributes biomass $\left(\sim 138\right.$ grams $(\mathrm{g})$ dry weight $\mathrm{m}^{-2}$ on average during optimum conditions) to nearshore environments that are otherwise relatively devoid of organic material (Eleuterius 1987). 
Seagrass beds in the Mississippi Sound lie exclusively on the north side of the barrier islands, mostly in waters shallower than $1.3 \mathrm{~m}$ and are typically patchy and discontinuous (Carter et al. 2011; Eleuterius 1987). These characteristics have remained consistent since the 1940s (Carter et al. 2011). However, these important seagrass ecosystems in the Mississippi Sound and globally are experiencing an overall decline due to sea-level rise, subsidence, and anthropogenic effects (Handley et al. 2007; Orth et al. 2006). The congressionally-funded, interagency, Mississippi Coastal Improvements Program (MsCIP) is currently restoring Ship Island to its pre-Camille volume and area using 13.5 million cubic yards of borrowed material (USACE 2014). The goal is to increase the island's stability and consequently the area habitable to seagrasses.

The seagrass response to the MsCIP in-filling of Camille Cut will depend on its sensitivity to shifts in environmental conditions like bathymetry, deposition, erosion, suspended solids concentrations, substrate particle size distribution, and relative wave exposure. This document describes the present state of these characteristics, and the ranges at which $H$. wrightii is currently stable on Ship Island. The present state of these characteristics will provide a prerestoration baseline that can be used for comparison after completion of restoration efforts on the islands (USACE 2014). This work also provides the foundation for more comprehensive studies with larger temporal and spatial scales to further establish critical relationships useful for planning, management, and restoration efforts.

\section{METHODS:}

SAV Surveys. Aerial imagery of East and West Ship Island were collected by Barry A. Vittor and Associates in 2010 (early summer) and 2014 (early fall). These images were used to delineate general areas of SAV growth (Figure 1) and were verified using field data to confirm the location and type of SAV growing in each polygon. Aside from several areas populated by algae and bryozoans along the southern shorelines and directly in Camille Cut, all polygons were populated by one seagrass species, Shoal Grass (H. wrightii, hereafter referred to as seagrass). A detailed description of the mapping and identification methods can be found in the Mapping of Submerged Aquatic Vegetation MsCIP Barrier Island Restoration Project Reports (Barry A. Vittor and Associates 2011, 2015).

The two surveys were taken during different parts of the growing season to capture seasonal variability. The 2010 early summer data should reflect the beginning of the growing season and minimum seagrass coverage. The 2014 early fall data should reflect maximum seagrass coverage (Carter et al. 2011). Both datasets show the same habitable zones with significant overlap; the 2010 data were collected with noticeably lower spatial resolution, and thus, not considered in this effort. All of the seagrass areas around Ship Island were patchy; hence, by definition less than $50 \%$ of the polygon area contains seagrass coverage (Barry A. Vittor and Associates 2011, 2015). These areas of patchy seagrass coverage are referred to as seagrass growth areas in this document. In the future, semi-automated patch boundary delineation methods, such as those used by Carter et al. 2011 could benefit seagrass monitoring efforts in this area. 


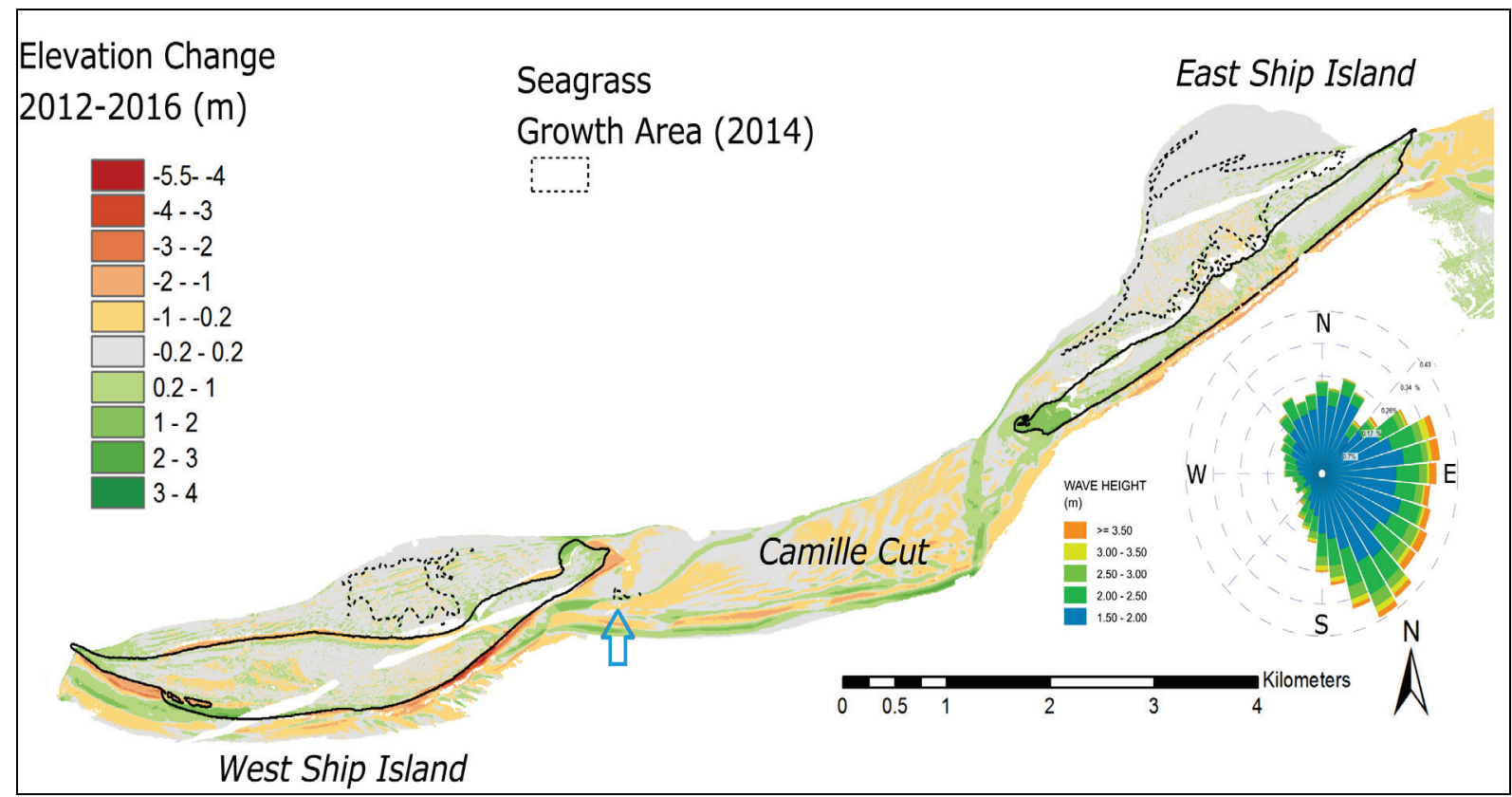

Figure 1. 2014 seagrass polygons shown on an elevation difference grid from 2012-2016. The blue arrow points out the small Camille Cut seagrass patch, red indicates erosion, and green indicates deposition. Gray shows areas of insignificant change in elevation (-0.2-0.2 m). A wave rose shows that the largest waves primarily come from the southeast (WIS station 73142). NAVD 88 shoreline.

Sediment Samples. Surface sediment grabs (45) were collected on 19 August 2015 in multiple locations to map the surface sedimentology around Ship Island, including seagrass growth areas (Figure 2). Sediment grabs were obtained from water depths ranging from $<1 \mathrm{~m}$ to $9 \mathrm{~m}$ around the islands and in Camille Cut. Particle size distributions of these samples were measured using a Malvern 3000 Laser Particle Analyzer and the D50 (mean - 50\% pass particle size) was calculated for each.

Suspended Solids. Suspended solids concentrations (SSCs) were measured around East Ship Island, West Ship Island, and in Camille Cut in August 2015 and February 2016, with many sites resampled for comparison (Figure 3). Depth casts were collected using a LISST-100X turbidity meter manufactured by Sequoia Scientific Inc. The instrument collected a measurement every second as it moved through the water column. Only data collected during the down-cast were used to prevent data inaccuracies caused by sediment resuspension at the sediment-water interface. These values were averaged, excluding surface (top $\sim 10 \mathrm{~cm}$ ) outliers caused by bubbles. 


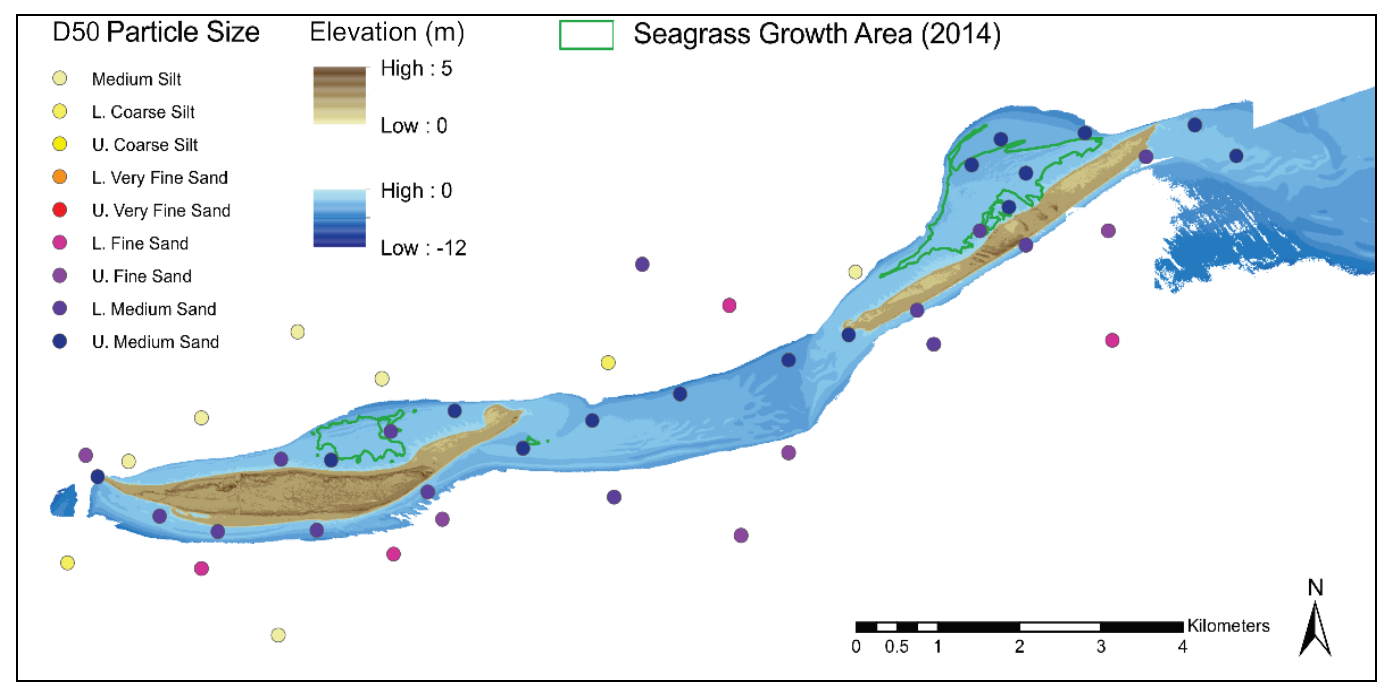

Figure 2. Sediment grab sample locations and D50 particle sizes collected August 2015.

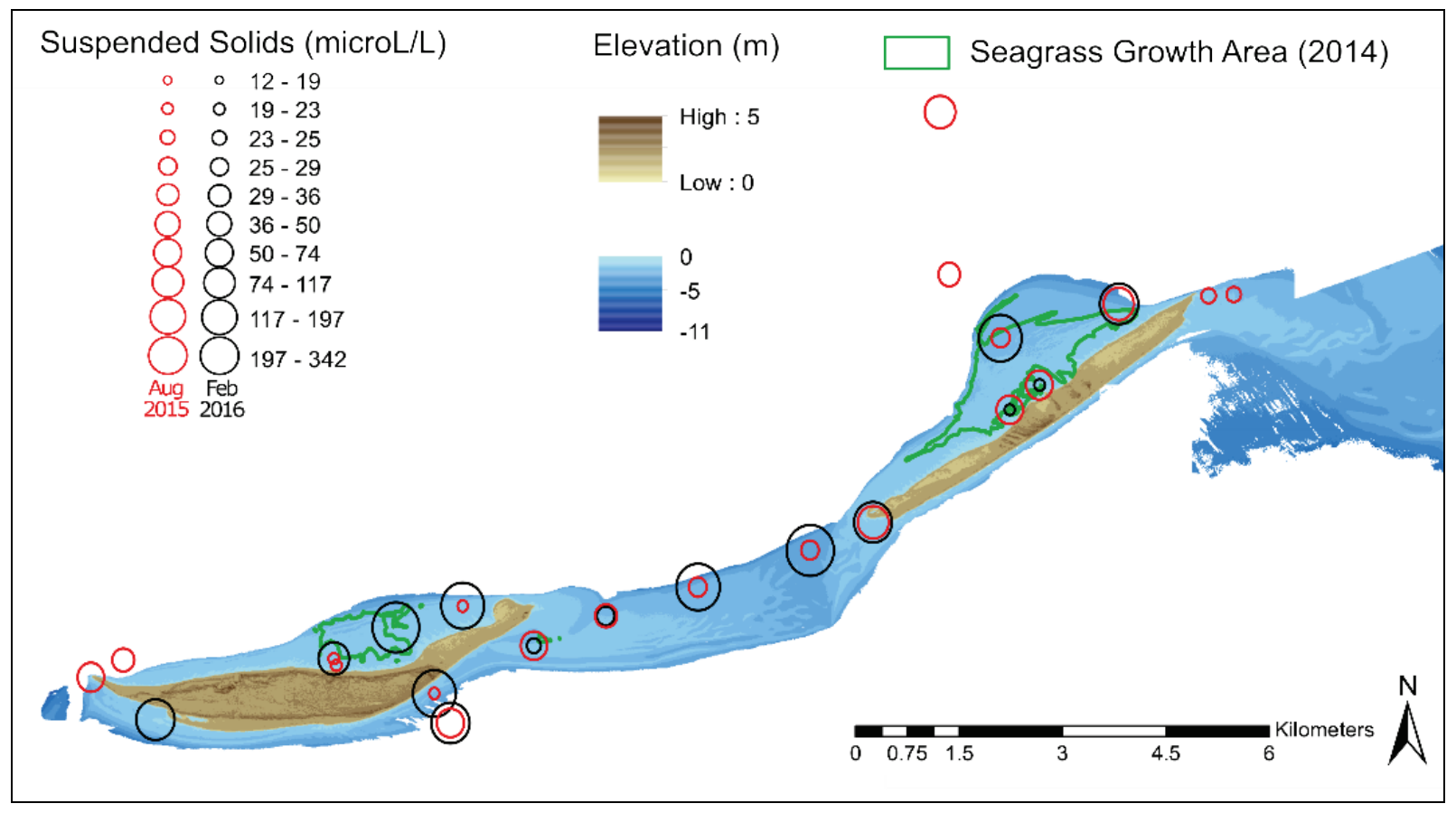

Figure 3. Average downcast suspended particulate concentrations collected in August 2015 (red circles) and February 2016 (black circles). Magnitude is indicated by the size of the circle; note the exponential scale.

Digital Elevation Models (DEMs). DEMs were produced from light detection and ranging (lidar) data collected by the Joint Airborne Lidar Bathymetry Technical Center of Expertise (JALBTCX), executed by the USACE National Coastal Mapping Program (NCMP). Elevation data collected in 2012 and 2016 were used, the closest available dates to the time of SAV surveys. Difference grids derived from these DEMs provide elevation change values from 2012 to 2016 (Figure 1). 
Analysis. The datasets containing information about SSC, particle size, DEMs, and difference grids around Ship Island, were spatially compared with the observed seagrass growth areas. The distributions of these variables inside and outside of the growth area show the type of physical setting the seagrass is currently experiencing relative to other areas around the island.

\section{RESULTS:}

Seagrass Distribution. The seagrass growth area was $1.6 \mathrm{~km}^{2}$ across the two islands in 2010 and $1.3 \mathrm{~km}^{2}$ in 2014 (Barry A. Vittor and Associates 2011, 2015). The East Ship Island area is considerably larger in both surveys (Figure 1). The shape and area of seagrass growth remained consistent from 2010-2014 (Barry A. Vittor and Associates 2015). One area of seagrass growth was mapped in the old western Camille Cut channel in 2014, but not in 2010 (Figure 1, blue arrow). The 2014 polygons are used for these analyses.

Bathymetry \& Bathymetric Change. Seagrass beds were observed in geomorphologically specific areas around East and West Ship Island. The patches exist on the shallow platforms extending into the Mississippi Sound to the north of the islands and in one location between sand ridges in the Western Camille Cut (Figure 2). The seagrass growth areas fall in a $2 \sigma$ range of -0.5 and $-1.9 \mathrm{~m}$ elevation in 2016 and -0.6 and $-2.0 \mathrm{~m}$ in 2012, deeper on average by $10 \mathrm{~cm}$ in 2012 (Figure 4). Seagrasses growing on the north side of the islands contribute the largest growth areas, and occur at similar depths, with the East Ship Island grasses occurring in water approximately $10 \mathrm{~cm}$ deeper in both 2012 and 2016. The small Camille Cut area of growth occurred in the deepest water in both years, and also showed the greatest average depth change, decreasing in depth by approximately $20 \mathrm{~cm}$ from 2012 to 2016 . Bathymetric changes within the seagrass patches from 20122016 are still minimal compared with other areas around the islands (Figure 1). Changes within the seagrass growth areas fall in a $2 \sigma$ range of $-0.3 \mathrm{~m}$ (erosion) to 0.6 $\mathrm{m}$ (deposition) between 2012 and 2016, translating to a range of $-7 \mathrm{~cm} / \mathrm{yr}$ to $15 \mathrm{~cm} / \mathrm{yr}$. In comparison, many areas on the southern shorelines of the island, exposed to the highest wave energy, experience changes of up to $1 \mathrm{~m} / \mathrm{yr}$.
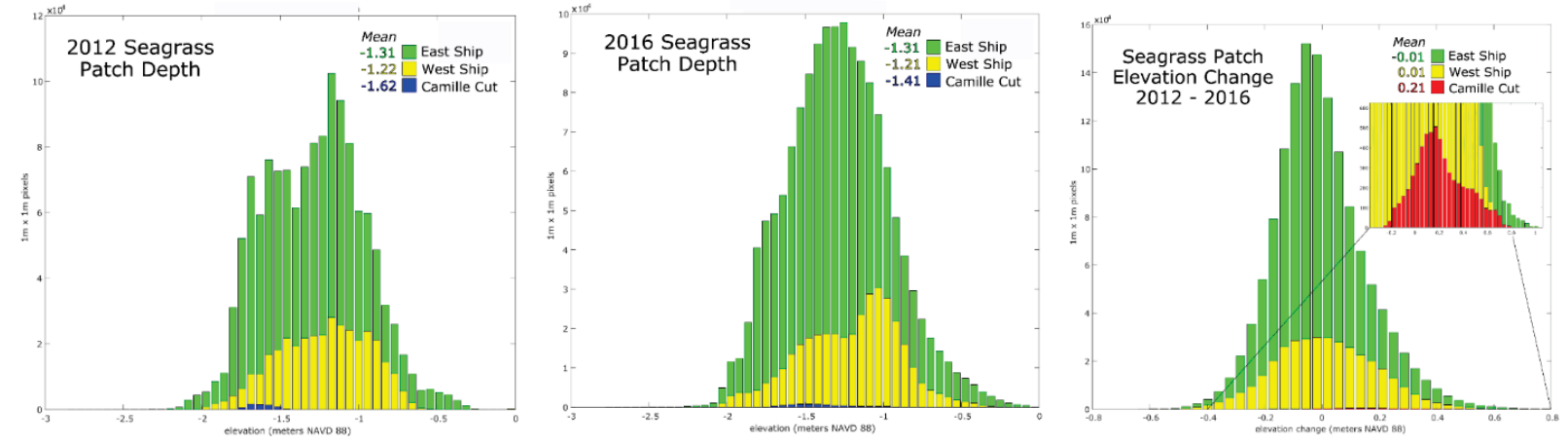

Figure 4. Elevations in seagrass growth areas measured in 2012 and 2016 (left and center, respectively). Total elevation change between 2012 and 2016 (right).

Sedimentology. D50 values for the grab samples ranged from 17.4-481.6 $\mu \mathrm{m}$ (silt to medium sand), and D90 values ranged from 94.4 to $803.5 \mu \mathrm{m}$ (very fine sand to coarse sand) (Table 1). The coarsest samples (D50 $>400 \mu \mathrm{m}$ ) exist in Camille Cut and behind East Ship Island (Figure 2). The finest samples $(\mathrm{D} 50<100 \mu \mathrm{m})$ were collected far offshore to the south of West Ship 
Island (Figure 2). There is a clear overall trend of coarser material in the shallow areas around the islands and finer material offshore. Within the seagrass polygons, D50 values ranged from 155 (fine sand) to $467 \mu \mathrm{m}$ (medium sand). Compared with the overall range of D50 values (17$482 \mu \mathrm{m})$, the seagrass grows in coarser sediment areas $(155-467 \mu \mathrm{m})$. The seagrass patches mapped on East Ship Island grew in coarser sediment than those on West Ship Island; however, particle size for both areas falls within the medium sand range $(250-500 \mu \mathrm{m})$.

\section{Table 1. Average particle size data $(\mu \mathrm{m})$ for the two largest patches of seagrass (patches 1 and 4). Overall particle size statistics show average values for all samples taken around Ship Island, both inside and outside areas with seagrass.}

\begin{tabular}{||l||c|c|c|c||c|c||}
\hline \hline & Ave D90 & Ave D50 & Max D90 & Min D90 & Max D50 & Min D50 \\
\hline \hline ES Large Patch & 610 & 388 & 770 & 320 & 467 & 155 \\
\hline WS Large Patch & 530 & 316 & 590 & 430 & 363 & 242 \\
\hline Overall & 458 & 269 & 804 & 94 & 482 & 17 \\
\hline
\end{tabular}

SSC. SSC values collected around Ship Island in August 2015 ranged from 11.9-45.5 $\mu \mathrm{L} / \mathrm{L}$, with an average of $26.1 \mu \mathrm{L} / \mathrm{L}$. Those collected in February 2016 ranged from 13.7-342.1 $\mu \mathrm{L} / \mathrm{L}$, with an average of $126.1 \mu \mathrm{L} / \mathrm{L}$ (Figure 3). These suspended solids concentrations capture the volume concentration of any material suspended in the water column, including living and dead organic matter, like plankton, as well as suspended sediment, so their relative contributions to the SSC cannot be quantified. There was no significant correlation between SSC and the areas of seagrass growth. The lowest SSC values were typically found on the north side of the islands; however, values on this side of the island were not always low.

\section{DISCUSSION:}

Bathymetry and Exposure to Waves. The seagrass areas of growth show a strong relationship with bathymetry. Patches of seagrass only exist in waters shallower than $2 \mathrm{~m}$ and only to the north/northwest of a protective feature. Growth in these areas can be attributed to several interrelated factors, including light penetration, particle size, suitable geomorphological setting, and wave protection. The Mississippi Sound bathymetry to the north of the islands is deeper and the sediment is finer-grained than the shallow platforms surrounding the islands, making bottom conditions unsuitable for photosynthetic organisms like seagrass. The seagrass itself is not limited by the particle size of the bottom substrate, but if the fine material contributes to increased turbidity, the particle size can become a limitation (Iverson and Bittaker 1986). Other locations around the islands, including Camille Cut and areas shallower than the two-meter depth range, are not populated with seagrass due to increased wave exposure (Figure 1, wave rose). Protection from waves is important for seagrass growth and establishment, and loss of protective sand bars has a negative relationship with seagrass growth (Fonseca et al. 2002). The formation of bars in the western Camille Cut channel formed a protected zone allowing seagrass to establish between 2010 and 2012 (Barry A. Vittor and Associates 2015). This zone is deeper on average than the other seagrass patches around Ship Island, suggesting that seagrass can grow in greater depths at locations with sufficient protection from waves and low turbidity. The sediment on the shallow shelves to the north of the islands is still within the zone of active sediment transport, thus creating a sandy substrate, reducing sediment-derived turbidity, and allowing more light penetration without exposing the grasses to high-energy waves. 
Erosion and Deposition. Lidar datasets from 2012 to 2016 show that the backbarrier shallow platform zones, where the majority of seagrass patches exist, have not experienced significant erosion or deposition over this time period. The seagrass tolerates rates of erosion and deposition on the order of $10 \mathrm{~cm}$ or less per year in its current environment around Ship Island (Figure 4). Aerial photographs reveal overwash deposits on the north shore of East Ship Island (Figure 5). These features are devoid of seagrass in both the 2010 and 2012 surveys. This may indicate that rapid overwash deposition is not favorable for seagrass growth and sustainability, possibly restricting the seagrass growth area to zones farther from the backshore of the islands where overwash occurs regularly. The spatial occurrence and extent of overwash is related to the geomorphological characteristics of the islands, such as dune elevation and stability,

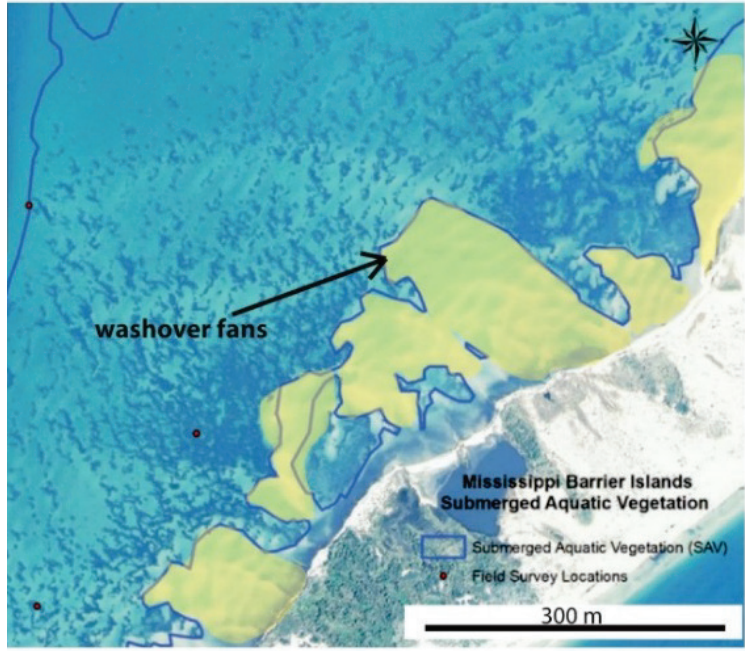

Figure 5. An up-close example of a polygon drawn around an area of seagrass growth on East Ship Island. Areas highlighted in yellow indicate washover fans. Figure modified from Barry A. Vittor and Associates, 2012. island width, beach width, etc. (Eisemann et al. 2018; Houser et al. 2008). The way these features control overwash in the system and the influence of overwash in seagrass growth has not been thoroughly examined. Only general relationships observed between seagrass growth and island geomorphology have been published in the scientific literature. In the MS-AL barrier chain, generally, the larger the island providing protection from waves, the larger the seagrass patches (Pham et al. 2014).

The Camille Cut seagrass growth area tolerated an average of $20 \mathrm{~cm}$ deposition between 2012 and 2016 (approximately $5 \mathrm{~cm} / \mathrm{yr}$ ), the largest average between the patches. This growth area is experiencing the most change due to its location in the active inlet, only protected by a subaqueous bar rather than a stable island. The bar sheltering this growth area from waves is expected to continue to shift, allowing the grasses to be buried or exposed to waves, making this growth area naturally the most vulnerable. A restoration effort in Tampa Bay observed that sand bars were most effective at increasing seagrass habitat when they were emergent during at least part of the tidal cycle, more effectively blocking oncoming waves (Fonseca et al. 2002).

SSCs. The SSCs presented in this report represent the volume concentration of all material suspended in the water column. Organic and inorganic material will both affect light penetration, yet their respective concentrations are controlled by vastly different processes. The data obtained does not distinguish between the organic and inorganic components; therefore, changing concentrations cannot be attributed to specific processes. The observed spatial patterns of SSCs are highly variable within each dataset and between the two data collection time periods, which could be attributed to various factors, including waves resuspending sediments, varying abundances of plankton, and suspended organic material. A more useful way of understanding the relationship between SSCs and seagrass growth may be to correlate long-term SSC averages with other data, such as wave height and wind speed. Turbidity is the variable most frequently 
correlated to light penetration and seagrass growth. SSC is correlated to turbidity in many locations, but the exact relationship varies from system to system (Chanson et al. 2007). This relationship has not been established for this study; hence, only SSC $(\mu \mathrm{L} / \mathrm{L})$ is reported. To compare these concentrations to previously published mass concentration values, the particulate is assumed to have the density of pure quartz $(2.65 \mathrm{~g} / \mathrm{mL})$. The volume concentrations collected here ranging from 10 to $300 \mu \mathrm{L} / \mathrm{L}$ are equivalent to mass concentrations ranging from approximately 30 to $800 \mathrm{mg} / \mathrm{L}$. These values fall within the reasonable range observed in coastal waters, but are higher than most observed in the Mississippi Sound, which typically range from 0-60 mg/L (Miller and McKee 2004). This difference could be attributed to the mixture of organic and inorganic material that composes the suspended solids, causing a reduction in density from that of quartz. The data collected in this study shows that SSC is highly variable around the islands, but within the order of magnitude observed in local studies.

\section{CONCLUSIONS:}

I. The limiting factors for seagrass growth in the shallow water around Ship Island, MS, include wave energy, depth, and rapid deposition, based on the growth areas observed and their relationship with these variables between 2012 and 2016.

II. Seagrass growth around Ship Island, MS, occurs only in areas protected from the prevailing south/southeast waves and in areas shallower than approximately $2 \mathrm{~m}$. In these areas, the substrate is composed of fine-to-medium sand and experiences a wide range of SSC on a seasonal basis $(10-300 \mu \mathrm{L} / \mathrm{L})$.

III. The most vulnerable seagrass growth areas are the Camille Cut growth area, which lacks stable protection from waves, and the areas close to the northern shorelines of East and West Ship Island, where the vulnerability to overwash is greatest.

IV. Future studies should define individual seagrass patches rather than large areas with less than 50\% vegetative coverage. Digital image analysis methods similar to those employed by Carter et al. 2011 will provide data comparable with most other published datasets. Performing more detailed spatial studies will allow for rigorous investigations leading to significant correlations and relationships between seagrass growth and the dynamic geomorphological features that provide their habitat.

ADDITIONAL INFORMATION: Research presented in this technical note was developed under the Environmental Management and Restoration Research Program (EMRPP). The USACE proponent for EMRPP is Mindy Simmons, the program manager is Dr. Trudy Estes, and the technical director is Dr. Al Cofrancesco. Technical reviews provided by Drs. Catherine Thomas and Matthew Balazik (ERDC Environmental Laboratory). The authors would like to acknowledge collaboration with the MsCIP. For additional information, contact the authors (information provided on the first page), or Dr. Trudy Estes (601-634-2125, Trudy.J.Estes@,usace.army.mil). 
This technical note should be cited as follows:

Eisemann, E. R., S. Altman, D. Acevedo-Mackey, and M. K. Reif. 2019. Relating Seagrass Habitat to Geomorphology and Substrate Characteristics Around Ship Island, MS. EMRRP Technical Notes Collection. ERDC/TN EMRRP-EBA-24. Vicksburg, MS: U.S. Army Engineer Research and Development Center. URL

\section{REFERENCES}

Boer, W. F. 2007. Seagrass-sediment interactions, positive feedbacks and critical thresholds for occurrence: a review. Hydrobiologia 591(1):5-24.

Byrnes, M. R., J. D. Rosati. S. F. Griffee, and J. L. Berlinghoff. 2013. Historical sediment transport pathways and quantities for determining an operational sediment budget: Mississippi Sound barrier islands. Journal of Coastal Research 63:166-183. http://doi.org/10.2112/SI63-014.1

Byron, D., and K. L. Heck, Jr., 2006. Hurricane Effects on Seagrasses Along Alabama's Gulf Coast. Estuaries and Coasts 29(6): 939-942.

Carter, G. A., K. L. Lucas, P. D. Biber, G. A. Criss. and G. A. Blossom. 2011. Historical changes in seagrass coverage on the Mississippi barrier islands, northern Gulf of Mexico, determined from vertical aerial imagery (1940-2007). Geocarto International 26(8): 663-673. http://doi.org/10.1080/10106049.2011.620634

Chanson, H., M. Takeuchi, and M. Trevethan. 2008. Using turbidity and acoustic backscatter intensity as surrogate measures of suspended sediment concentration in a small subtropical estuary. Journal of Environmental Management 88(4):1406-1416. https://doi.org/10.1016/j.jenvman.2007.07.009

Dawes, C. J., 1987. The dynamic seagrasses of the Gulf of Mexico and Florida Coasts. Florida Department of Natural Resources, Burea of Marine Research. St. Petersburg, FL. Florida Marine Research Publications 42: $25-52$.

Eisemann, E. R., D. J. Wallace, M. C. Buijsman, and T. Pierce. 2018. Response of a vulnerable barrier island to multi-year storm impacts: lidar-data-inferred morphodynamic changes on Ship Island, Mississippi, USA. Geomorphology 313:58-71. https://doi.org/10.1016/j.geomorph.2018.04.001

Eleuterius, L., 1987. Seagrass ecology along the coasts of Alabama, Louisiana, and Mississippi. Florida Marine Research Publications 42:11-24.

Fonseca, M. S., B. D. Robbins, and P. E. Whitfield. 2002. Evaluating the effect of offshore sandbars on seagrass recovery and restoration in Tampa Bay through ecological forecasting and hidcasting of exposure to waves. Mote Technical Report; No. 851. Sarasota, FL: Mote Marine Laboratory.

Handley, L., D. Altsman, and R. DeMay, 2007. Seagrass status and trends in the northern Gulf of Mexico: 19402002 (Report Version 1.). Reston, VA: Scientific Investigations Report. http://pubs.er.usgs.gov/publication/sir20065287

Houser, C., C. Hapke, and S. Hamilton. 2008. Controls on coastal dune morphology, shoreline erosion and barrier island response to extreme storms. Geomorphology 100(3-4):223-240. https://doi.org/10.1016/j.geomorph.2007.12.007

Iverson, R. L., and H. F. Bittaker, 1986. Seagrass distribution and abundance in Eastern Gulf of Mexico coastal waters. Estuarine, Coastal and Shelf Science 22(5):577-602. http://doi.org/10.1016/0272-7714 (86)90015-6

Kirwan, M. L., and J. P. Megonigal. 2013. Tidal wetland stability in the face of human impacts and sea-level rise. Nature 504:53-60.

Koch, E. W. 2001. Beyond light: Physical, geological, and geochemical parameters as possible submersed aquatic vegetation habitat requirements. Estuaries 24(1): 1-17. 
Livingston, R. J., S. E. McGlynn, and X. Niu. 1998. Factors controlling seagrass growth in a gulf coastal system: Water and sediment quality and light. Aquatic Botany 60(2):135-159. https://doi.org/10.1016/S03043770(97)00079-X

McBride, R. A., and M. R. Byrnes. 1997. Regional variations in shore response along barrier island systems of the Mississippi River Delta Plain: Historical change and future prediction. Journal of Coastal Research 13(3): 628655. https://www.jstor.org/stable/4298660

Miller, R. L., and B. A. McKee. 2004. Using MODIS Terra $250 \mathrm{~m}$ imagery to map concentrations of total suspended matter in coastal waters. Remote Sensing of Environment 93(1-2): 259-266. https://doi.org/10.1016/j.rse.2004.07.012

Miller, R. L., B. A. McKee. 2004. Using MODIS Terra 250 m imagery to map concentrations of total suspended matter in coastal waters. Remote Sensing of Environment 93:259-266. https://doi.org/10.1016/j.rse.2004.07.012

Moncreiff, C. A. 2007. Mississippi Sound and the Gulf Islands. In: L. Handley, D. Altsman and R. DeMay, eds. Seagrass status and trends in the Northern Gulf of Mexico: 1940-2002. U.S. Geological Survey Scientific Investigations Report 2006(5287):77-86.

Morton, R. A. 2008. Historical changes in the Mississippi-Alabama Barrier-Island Chain and the roles of extreme storms, sea level, and human activities. Journal of Coastal Research 246(6):1587-1600. http://doi.org/10.2112/07-0953.1

Orth, R. J., T. J. B. Carruthers, W. C. Dennison, C. M. Duarte, J. W. Fourqurean, K. L. Heck, A. Raneall Hughes, G. A. Kendrick, W. J. Kenworthy, S. Olyarnik,F. T. Short, and S. L. Williams. 2006. A global crisis for seagrass ecosystems. BioScience 56(12):987. http://doi.org/10.1641/0006-3568(2006)56[987:AGCFSE]2.0.CO;2

Otvos, E. G., and G. A. Carter. 2008. Hurricane degradation - barrier development cycles, Northeastern Gulf of Mexico: Landform evolution and island chain history. Journal of Coastal Research 24(2):463-478. http://dx.doi.org/10.2112/06-0820.1

Otvos, E. G., and G. A. Carter. 2013. Regressive and transgressive barrier islands on the North-Central Gulf Coast contrasts in evolution, sediment delivery, and island vulnerability. Geomorphology 198:1-19. http://doi.org/10.1016/j.geomorph.2013.05.015

Pham, L. T., P. D. Biber, and G. A. Carter, 2014. Seagrasses in the Mississippi and Chandeleur Sounds and problems associated with decadal-scale change detection. Gulf of Mexico Science 32:24-43. https://doi.org/10.18785/goms.3201.03

Twichell, D. C., J. G. Flocks, E.A. Pendleton, , and W.E. Baldwin. 2013. Geologic controls on regional and local erosion rates of three northern Gulf of Mexico barrier-island systems. Journal of Coastal Research 63:32-45. http://doi.org/10.2112/SI63-004.1

U.S. Army Corps of Engineers (USACE). 2014. Mississippi Coastal Improvements Program (MsCIP) Comprehensive Barrier Island Restoration. Hancock, Harrison, and Jackson Counties, Mississippi. Supplemental Environmental Impact Statement. Washington, DC: U.S. Army Corps of Engineers (USACE).

Vittor, B. A. and Associates, Inc., 2011. Mapping of Submerged Aquatic Vegetation in 2010. Final Report. Mobile, AL: Mississippi Barrier Island Restoration Project.

Vittor, B. A. and Associates, Inc., 2015. 2014 Mapping of Submerged Aquatic Vegetation. Final Report. Mobile, AL: Mississippi Coastal Improvements Program (MsCIP).

Yates, K. K., G. Morrison, and H. Greening. 2011. Seagrass: Integrating Science and Resource Management in Tampa Bay, Florida, 63-104. http://pubs.usgs.gov/circ/1

NOTE: The contents of this technical note are not to be used for advertising, publication, or promotional purposes. Citation of trade names does not constitute an official endorsement or approval of the use of such products. 